\title{
The Third Person Polite
}

\author{
Dôre Michelut
}

\section{À la troisième personne}

Voici un texte où le je veut cesser de s'absenter, ne plus parler à la troisième personne. Qui est cette personne qui est moi et dont on parle et que je ne reconnais pas? Jeu incessant, presque schizophrénique, qui se double du rapport avec l'Autre, qui est, lui aussi, tour à tour un je et un il ou elle, et où l'auteure cherche un ancrage à sa parole. Cet écran entre moi et l'autre, entre moi et le monde réel, comment le traverser? Parmi tous ces rôles, quel est le mien, qui suis-je?

Everyone says that I did not speak a single coherent word until I was almost two. Then something happened and I spoke suddenly, fluently and, they say, I haven't stopped since.

The event that caused me to speak is given to me in words, and with words, I claim that story for myself. I believe it, yet I do not really understand it, for the event is not mine: I do not remember it.

This is the story. It took a camera to make me talk. I was two years old and hadn't spoken a single, coherent word. Everyone worried that something might be wrong because all I did was babble. One day, the photographer was called to take the family portrait. That's when it happened. Just as this picture was being taken, I spoke. I'm the little girl holding up the flower, see, I'm talking: my mouth is open, my eyes are occupied. That woman standing so straight is my mother, and the boy beside me is my brother.

There are some memories which are mine, I know them to be mine because they are precise events I can locate in myself and recount. I can speak of them as concretely as I can speak about this picture. For instance, I know the ache in my back as I pick string beans, the bushel overflows spilling yellow on the black Schomberg earth; the dense boredom of Maestromateo's grade eight class bursts as Raymond slips me a ball point doodle of a shark; a staccato cackle of hens 
punctures the cicada drone in the dappled sunlight under the vines in the Ariis courtyard; as I walk past tattered plastic bags and used condoms on the trodden bank of the Arno on market Tuesday, I bite into a salt pork sandwich fragrant with rosemary.

But these are events which have been tamed, rendered harmless by a time I have been able to hold still and shape by memory. So why do I accept as my own a story I can't remember, the story everyone tells me, that I did not speak till I was two years old? If I make myself by remembering the self, who is this She everyone remembers, that familiar She that I haven't made, the She who speaks me. And why do I take her as given, accept her as me, mine?

Because She already exists. Everyone remembers Her. She is there. Everyone tells me so. And I trust that the event is as exact a piece of time as this black and white picture is a location in space. That means that She is guaranteed real, safe, while I am still dangerous, a terra incognita.

Remembering the self is dangerous. I will trust my personal memory only so far, for I sense that my use of it doesn't even scratch the surface of what memory is capable of. I do know that memory is that which makes me perform: it makes me for the sake of (per) form. I fear it could be any form, perhaps even something impossible to put words to, without meaning. And that is the most frightening thing I know. For example: my mother has been dead for years, yet when I focus, I sense that she comes. As much as I dare let her. If at this very instant I could let go and remember her completely, she would come completely. She would stand before me. That is why I limit my memory. I fear it will lead me to a place where no words will follow and then, perhaps I will lose everyone, including mother. So until I find a better way, I will go only as far as I can take language. My question is: how do I remember Her, the She that is given to me?

It does not feel as if there is a single reason that stops Her, in the picture, from speaking, it feels as if it has more to do with the pressure and the timing of that which bears Her. The sensation of expansion is there, that is all. It seems that She just keeps on being born. Whatever She lays Her eyes upon or touches swells Her and She grows until She becomes aware of the sensation of being ominous. She feels a premonition like a wave must feel when the surge is about to spend itself. She babbles, but the tone of it sounds as if an event is starting to make itself felt; something hovers, like a curse or a malicious intention. 
Mother feels it as well because she always puts Her left sock on inside out to ward off the evil eye. This is something else everyone tells me, along with the fact that the first word She utters is 'no.' I like this. It feels right. I want to believe it, to think that at the tender age of two, I have already figured everything out.

Something impending. A no. A uniform no, dense, intense. No, the pain, the smith, the shaper. No-you-are-not-me: pain. No-you-arenot-food: pain. No, I cry, and that sound becomes a word which describes a relationship I am born into. Nos cluster to form such complex words that their very sound creates feelings. Each sound is a birth into an element which is not me, in which I learn to move. As a blind person moves by tapping a cane, I come to move by sounding words. I sense that it is this freedom, the possibility of directing movement away from pain, that finally seduces Her and She yields to speech.

Still, I can't penetrate the old, waxy black and white picture. The moment. At a certain point that rigid female is my mother; that wideeyed boy holding me by the arm at that same point is my brother. I cannot go further. Already I feel terror. I go as far as I can: that is, I stop at the vertigo and scuttle back, find a context, locate everyone, reconnoitre.

Mother is raised during the last throes of the feudal era. Bicycles are seen in the area only a few years before her birth. She remembers her grandfather, the one with the key to the pantry, taking apart the radio to find the little man inside. Mother grows up in the presence of the space miracles provide. With her mind, she tries out the dangers of freedom: she imagines herself Nila Pizzi, the voice singing on the radio; or, watching the countess pull away in a car, she multiplies the thrill of speed needed to keep balanced on a bicycle. But she has my same problem: there are no words in the make-up of her world for the places she discovers in her mind.

The four roads leading out of town lead to towns just like hers. They are places that she can recognize and predict because they are like hers: the earth is subjected to work, work to the family, the family to the baronage and the baronage to the myth of freedom.

Everyone in town knows the count and countess personally. Everyone knows their penchants and the particulars of their toilet. Everyone knows their curses, their intimate gestures, yet no one in town can replace them. As individuals, it doesn't really matter who they are. 
Stories tell, saints or murderers, they have always been fully accommodated. An aristocracy is evidence that one's humanity is more than drudgery. It completes the body politic by actively funnelling myth. Without the performance of the aristocracy, the feudal world would disappear: the peasants would never accept such drudgery as the human lot.

And fate, of course, is not a personal matter. There is a script: omnipresent and omniscient. Since God has gone to the trouble of writing it down, everyone's memory is constantly refreshed. To change even a simple pattern of this language, the entire social structure would have to change. Language, therefore, is everything.

Only within the script can the boundaries of myth and reality be negotiated. And to ensure that the roles are unmistakably defined, when roles interact, the polite form is used. The third person polite is the key with which to enter a current of power capable of patterning the 'nos' of language differently. It is an ironic form, a grammatical alienation: the referent happens outside of language in the myth of freedom where an alternate reality is contracted. It serves to reconcile the birthright of life to the script in a forum, a public sphere. When the third person polite is used, God listens.

This is how I understand it: the polite form commands respect, but the respect is not necessarily reciprocal. The countess herself doesn't give a damn what the peasants think of her. Socially, they are not her limit. In fact, she addresses them in the second person familiar, neatly subsuming them. Yet, her movements do not correspond sympathetically to peasant rhythms. She is served by the peasants, fed by them, maintained by them, yet they are not her audience. This frees her of their constraints. In my mind, she floats over them like a helium balloon anchored by a cord, as dependent as a foetus. If she were to do the work that mother does in a day, she would collapse. But according to mother, the countess is free, open-ended. She embodies a place where mother constructs her freedoms, a place where the 'nos' of her solid world are held in check and kept at bay by the sheer force of the polite form.

But here, in the photograph, in the heart of that momentous afternoon, yes, it's early afternoon, where She is holding Herself inside the process of being born, where She resists everyone, resists the foreboding pull at Her birthright, She has no understanding that the babble 
that rises from within intends to sever and contain Her. She can't make that connection between the patterned sound surrounding Her and life, Her birthright. Closer, but not close enough. What do I need to sustain this memory?

Language. This picture makes sense only in Furlan. Furlan is my mother tongue. Perhaps because of the continual violence between Celt and Vulgar Latin, Furlan has a particularly large number of nos behind it. Each word is so heavy and tight that its patterns sharpen the flesh until speech reaches pointedness. In Furlan, I can still focus on anything and say 'no' with utter certainty. Perhaps that's the reason I lose the capacity to speak Furlan when we emigrate. When my mother speaks, I reply in English.

I am six when Furlan concedes to English, young enough, I guess, to remind me that I have known sound to be meaningless. Such complete re-immersion into an unknown body of sound teaches me that the nos are not ultimate; it reminds me of my birthright, that I have a choice, that I can be anything, that I am free to feel life surging. A few days after we emigrate, I stand in the next door neighbour's front yard with an arm around their tree, happily babbling to passersby for hours. In English, I feel the surge again, and I let myself be carried out, over and above the dams, released from all those excavated places. Mother's iron grip is loosened; she can't reach me in English, I can stop the nos she insists on passing on.

No wonder I embrace English unconditionally, wholeheartedly: I assume that what happens to me happens to everyone because everyone in English is free of the Furlan nos. I assume that in freedom I speak unanimously, that I contain everyone. And I assume that in this language others speak freedoms which include me. Such familiar assumptions! How am I to know that universal freedom is an illusion that happens because English has no polite form, no built in mechanism for keeping what is familiar separate from myth.

What a terrible misunderstanding. I go through a lot of grief before I realize that in English, to be familiar is an insult. Many years pass before I finally understand that rather than erase the formal sphere in favour of the familiar, English renders everything formal all the way across the social spectrum right down into each individual self. The polite form is not eradicated but made ubiquitous. In English, I can assume no familiarity, in fact, sometimes I feel that even the self is 
made strange. Just how reality is negotiated in English is still beyond me. Often I've thought that English perhaps is bent on the personal becoming social rather than social becoming.

But Furlan is in flux too. Going further back in time, it gets stranger: they say that only in this century the polite form has become the third person singular. A hundred years ago the polite form is constructed with the second person plural. My great grandmother would address my great grandfather YouPlural.

That means, I imagine, that women would have submitted a priori to all men: as the peasant was to the count, the wife was to the husband. I can picture the wife disappearing before her husband, subsumed by a familiarity that assumes his identity. I guess that's why I feel that the Furlan nos are so wicked. I wonder how they became intimate enough for her to have born twelve children. But procreation doesn't need intimacy, really. Quite the contrary, the species does just fine in the realm of the familiar. Proof that language and biology are distant cousins. No wonder memory frightens me.

Back to the picture: She's looking up at my mother who is standing so straight she could be at attention. All around there are flowers, geraniums, I think. I've plucked one and I'm holding it up with my right hand, my brother is gripping my left arm, rather impatiently. Well, that hasn't changed. He's still impatient.

Yes, I accept English wholeheartedly. But for my poor mother it's too late and the loss of the polite form is a tragedy. Years after she emigrates, her children more and more obstinately English, she loses the capacity to address the countess inside.

Mother loses the countess little by little. She tries hard to impose her on me but nothing in our English world needs her, and I prefer to shut her out and watch Jane Fonda kissing on TV where the mechanics of the flesh are closer to the crux of adolescence. Who cares about bowing and scraping to a cranky old lady who keeps her skin white so that she will not be mistaken for a peasant; who walks with a definite tilt of the nose and a sideways dart of the eyes; who makes entrances down staircases and has a passion only for flowers. Katherine Hepburn does it better on TV without an audience of peasants. We do not recognize the place of the countess in mother and we squirm when she assumes this role to talk to the teacher on parent's night and to the priest on Sundays. Such a bad performance and it gets worse as the years go on. 
A turning point comes when mother finally learns to say the word love in English. In Furlan there is no equivalent, tender words happen in an intimate space that acknowledges a difference conquered from familiarity. The English word for love is an awareness that the other is another, and responds independently. The moment mother utters the words I love you, the countess within her starts to decay. She has been betrayed, and no matter how much mother watches late night shows to learn to identify with Jane Fonda, it is too late to say love. She feels the terror of the sharp Furlan 'nos' closing in, strangling her myth of freedom in the absence of the countess.

But thirty years before, mother grips the countess like a vice. She speaks the polite form everywhere she can. Her favourite is the priest. He understands perfectly. He knows all about the polite third person since he speaks like that to God in Latin all the time, never mind that he talks of life as sin and tells her to submit. And she can forget, comply, since he upholds the only place inside where she is free from the 'nos.'

The family calls the photographer who comes for the first time since the last feudal law is abrogated five years ago. Machinery has been introduced and the peasantry is not needed in bondage. The extended families of the peasants are granted a house and a bit of land if they served a count for more than twenty years. The political slogan: terra ai contadini, (land to the peasants) at that point is ludicrous since they are all legally day workers. Cecchelin, a Triestine stand-up comic becomes famous all over Friul for one of his lines: "Give land to the peasants - and the cemetery to the dead." The peasants as a class are dead; now their bodies are dying of hunger. Everyone is frightened. Suddenly, there is a new script but no one knows their role. Although everyone is 'freed' from the land, there is no new pattern in reality. Abundant, abstract social space abounds, but there is no language to deal with that new reality. There are no jobs to be found. My father emigrates alone to work on the Canadian railways. We are lucky. He is one of the chosen. He is leaving us. That is the event.

She stands in front of the camera, not realizing the gravity of the moment, simply being part of, oh yes, part of the day. It is early afternoon and so sleepy that the cicadas are deafening, rubbing their wings together like that. It happens close to the age-old manure pile because that is where most of the flowers are and mother wants him to remember his family among the flowers. 
She points to the swallow that dips under the terracotta shingles of the roof of the house that is sleeping grandmother, cousins, aunts, uncles. The air is fresh on the skin because it has rained. Close behind is the winter wood pile and the ploughed earth is just five meters away sending wafts earthworm that mingle with the pungent odour of manure. And She stands in front of the camera, happy, as She would be happy everywhere. She reaches out and picks a large red geranium because perfume is closer.

Mother is unhappy in the Sunday dress that she has worn every Sunday for the past two years now. The rabbits she is allowed to keep and sell for herself have all died and to wear last year's Sunday dress is such a great humiliation. Poverty and the family tell her: no, you can't be the polite third person this year, not even on Sundays because we can't afford it. But mother tries. For all the futures she sees in her freedom when she looks back at this photograph, she tries. Hurriedly, she powders her face, then proudly squares her full body straight, pulling her skull back so that her nose lifts just slightly.

With the knowledge of being everything, She knows it is hard for mother to find the countess inside. Up mother, up, just a little more and it will be perfect. She wants to help. She holds up the crushed geranium to help. Her offering permeates the air altering the dank latrine and earthworm smell and She sees mother breathe deeply and smile and the pain in my chest is something She cannot tolerate. She says "No," She says, "Mother, No." 